\title{
Spermatozoal ultrastructure of the hermit crab Loxopagurus loxochelis (Moreira, 1901) (Decapoda: Anomura: Diogenidae) from the southwestern Atlantic
}

\author{
Marcelo A. Scelzo, Antonio Medina and Christopher C. Tudge
}

\begin{abstract}
The spermatozoal morphology of Loxopagurus loxochelis exhibits characters shared by other paguroids: complex concentrically zoned acrosome vesicle, capped by an electron-dense operculum and posteriorly penetrated by a large perforatorial chamber, and three microtubular arms emanating from the cytoplasm. The general sperm cell dimensions and arrangement of the acrosome in $L$. loxochelis are similar to those previously described for three species of Calcinus. However, Loxopagurus lacks a defining autapomorphy of this genus: splitting of the anterior end of the perforatorial chamber into many obvious fingers. The only unique character observed in the sperm of Loxopagurus is the presence, in the cytoplasm, of a bulge filled with small tubules on the side of the acrosome. This structure could be an artifact or possibly a parasitic bacterial infection. In conclusion, L. loxochelis sperm morphology does not demonstrate any clear autapomorphies, but seems to separate from the other genera in the Diogenidae by the absence of their defining sperm characters (e.g. anterior perforatorial fingers and microvillar projections). It appears most similar to the genus Calcinus, and more superficially Strigopagurus, although its spermatophore morphology seems to indicate a closer relationship with Clibanarius. The combination of spermatophore and spermatozoal characters clearly places it in the Diogenidae, and supports its monotypic status.
\end{abstract}

\section{INTRODUCTION}

The anomuran crustaceans include a wide variety of forms ranging from the eye-catching hermit crabs to commercially valued species such as the king crabs. Some anomuran species are semiterrestrial, or freshwater, but most are marine, inhabiting a broad bathymetric range, from littoral to deep waters. According to McLaughlin (1983), McLaughlin \& Holthuis (1985), and Martin \& Davis (2001), the Anomura comprise the superfamilies Lomisoidea, Galatheoidea, Hippoidea, and Paguroidea. The superfamily Paguroidea, to which the familiar hermit crabs and king crabs belong, includes the Coenobitidae, Diogenidae, Paguridae, Parapaguridae, Pylojacquesidae, Pylochelidae and Lithodidae (McLaughlin \& Lemaitre, 2001; McLaughlin, 2003). The anomuran family Diogenidae is considered an ancient monophyletic group (Forest, 1995) and is a morphologically diverse taxon currently encompassing 19 genera (McLaughlin, 2003). In Argentinian waters, three families, six genera and ten species of "hermit crabs" have been found (Forest \& Saint Laurent, 1967; Scelzo, 1971, 1973; Scelzo \& Boschi, 1973; Boschi et al., 1992), four of them belonging to the Diogenidae.

Loxopagurus is a monospecific genus in the Diogenidae. The species Loxopagurus loxochelis (Moreira, 1901) is endemic to the southwestern Atlantic Ocean, being one of the most common hermit crabs that inhabit shallow littoral waters off Brazil, Uruguay and Argentina, down to a depth of 30 meters (Boschi et al., 1992; Melo, 1999). The biology of this species is reasonably well known (Moreira, 1901; Forest \& de Saint Laurent, 1967; Scelzo \& Boschi, 1973; Scelzo, 1976; Rieger \& D'Incao, 1991; Martinelli et al., 2002). The life cycle of $L$. loxochelis has been studied recently in the Ubatuba region (São Paulo State, Brazil), where the occurrence of exobionts on occupied shells, shell utilization pattern, relative growth, 
and spatial distribution have been investigated (Martinelli \& Mantelatto, 1998, 1999; Mantelatto \& Martinelli, 2001; Mantelatto et al., 2004). Some aspects of the reproductive biology, particularly larval development (Bernardi, 1986), spermatophore morphology (Scelzo et al., 2004), and molecular phylogeny (Mantelatto et al., 2002) have been examined in recent years.

Comparisons of the functional morphology of genitalia and subsequent sperm transfer and storage mechanisms among taxa can provide useful information on phylogenetic relationships and evolutionary divergence, especially in the Decapoda (Bauer, 1986, 1991). Cladistic, molecular systematics, developmental genetics, sperm morphology, larval morphology and the fossil record are the main research fields used in the classification of recent crustaceans (Martin \& Davis, 2001). The description and comparison of sperm ultrastructure are termed "spermiocladistics" (Jamieson, 1991), and according to Tudge (1997), the "use of spermatozoal ultrastructure in taxonomy and phylogeny is now firmly established as a valid means of investigating phylogenetic relationships in various animal phyla."

Mature decapod spermatozoa are aflagellate, immotile and have an uncondensed nucleus (Krol et al., 1992). The noncaridean, pleocyemate decapods share a common sperm form consisting of a large acrosomal vesicle, a posterior nucleus of variable density, intervening cytoplasm containing mitochondria, microtubules, lamellar structures, and often centrioles, and a variable number (from three to many) of arms or spikes. The arms may be composed of nuclear material (higher Brachyura), microtubules (Anomura), or both (Majidae in Brachyura) (Tudge, 1992, 1997), and in most anomurans the arms have a cytoplasmic origin (Hinsch, 1991; Tudge et al., 2001; Tudge \& Scheltinga, 2002). Centrioles lie between the acrosome and nucleus and persist in the mature spermatozoa of some anomuran species. The conclusion from sperm ultrastructure that the Anomura sensu stricto are the sister group of the Brachyura (Jamieson \& Tudge, 2000) is endorsed by somatic cladistic study (Scholtz \& Richter, 1995). The basic sperm morphology among the Anomura is similar to that found in the Brachyura, but the main differences lie in the acrosome shape and zonation (Tudge, 1992, 1995a, b).

This is the first ultrastructural description of the sperm of Loxopagurus. The Diogenidae is one of 13 anomuran families for which the sperm morphology of at least one representative has been described (Tudge, 1992, 1995a, b, 1997; Tudge \& Jamieson, 1991, 1996a, b; Tudge et al., 1998, 1999, 2001; Jamieson \& Tudge, 2000, and references therein; Tudge \& Scheltinga, 2002). The Diogenidae is an anatomically diverse family and exhibits a range of sperm morphologies intermediate between the Paguridae and Coenobitidae which may indicate a diphyletic origin for this family (Tudge, 1995a, b, 1997). At present, 21 species belonging to six genera in the Diogenidae are described for sperm ultrastructure (see Table 3 in Jamieson \& Tudge, 2000, and additionally Matos et al., 1993 and Manjón-Cabeza \& García Raso, 2000).

This study describes and illustrates the ultrastructure of the spermatozoa of Loxopagurus loxochelis and compares it to that of other investigated members of the Diogenidae and Paguroidea in general.

\section{MATERIALS AND METHODS}

Hermit crabs Loxopagurus loxochelis were caught from 1999 through 2002 (Scelzo et al., 2002) off Mar del Plata (Buenos Aires Province, Argentina) at depths between 5 and 20 meters. Adult individuals were transported alive to the laboratory at Mar del Plata National University, Argentina (UNMdP).

Small fragments of testes, vasa deferentia and ejaculatory ducts were fixed for 3-4 hours in $3 \%$ glutaraldehyde in $0.2 \mathrm{M}$ phosphate buffer (pH 7.2) containing 1-3\% sucrose. After three 15 -min washes in phosphate buffer, the samples were postfixed for 80 minutes in $1 \%$ osmium tetroxide in phosphate buffer, washed in buffer and then processed for scanning (SEM) 
and transmission (TEM) electron microscopy. Fragments of the terminal ampulla destined for SEM were dehydrated in an ascending series of acetones, critical-point dried, sputter-coated with gold, and examined in either a Jeol JSM 820 (Cádiz University, Spain) or a JSM 6460 LV (Mar del Plata National University, Argentina) scanning electron microscope. For TEM, samples of the reproductive system were dehydrated through an ascending series of alcohols (ethanol) $50-100 \%$ and embedded in Spurr' s epoxy resin (Spurr, 1969). Thin sections ( 80 $\mathrm{nm}$ ) stained with uranyl acetate and lead citrate (Reynolds, 1963) was examined in a Jeol 1200 EX transmission electron microscope operated at $80 \mathrm{kV}$.

\section{RESULTS}

Spermatophores were observed at the light and SEM level. The spermatophores, which are between 100 and $600 \mu \mathrm{m}$ in size, elongate and pedunculate, have a small, flattened spherical ampulla on top of a long thin stalk. A double spermatophore ribbon is attached to the internal lining of the vas deferens by the base or pedestal (Fig. 1A, B). Each ampulla contains many spermatozoa (Fig. 1C). For a detailed description of the spermatophore morphology see Scelzo et al. (2004).

The free spermatozoa are medium-sized cells (approx. $6 \mu \mathrm{m}$ in length) with an obvious ovoid acrosome vesicle occupying most of the cell (Fig. 1C-E). When viewed dorsally, an operculum is seen on top of the acrosome vesicle, but when viewed ventrally the sperm cells have a granular area of cytoplasm and nucleus interrupted centrally by an ovoid perforatorial chamber. Three short arms (usually only one or two are visible) extend from blunt projections of the spermatozoal outline (Fig. 1C-E). These blunt vertices are often apparent even when the accompanying arms are not visible.

At the TEM level, the three components of the spermatozoa are clearly visible (Fig. 2AC). A large, densely staining, slightly elongate ovoid acrosome vesicle occupies the apical pole of the cell, an amorphous, electron-lucent, nucleus occupies the opposite pole, with the heterogeneous cytoplasm intervening and displaced laterally around the acrosome vesicle (Fig. 2A, B). In longitudinal section (LS) through the mid-line of the cell, the spermatozoa average $6.7 \mu \mathrm{m}$ in length $(n=3)$ and 4.5 $\mu \mathrm{m}$ in width $(n=3)$, including any projections of the nuclear material (excluding the arms).

The acrosome vesicle, in LS, has a mean length of $3.3 \mu \mathrm{m}$ and mean width (at widest diameter) of $2.8 \mu \mathrm{m}(n=7)$, giving it an average length to width ratio of 1.2 . This extended ovoid-shape is consistent throughout all spermatozoa recorded for this species, and they have a shallow conical operculum and a large, deep perforatorial chamber opposite this (Fig. 2B). Both structures are seen to be circular when viewed in transverse section (TS) (Fig. 2D) or at the light microscope level. The maximum diameter of the operculum averages $1.7 \mu \mathrm{m}(n=$ 4) and $80 \mathrm{~nm}$, or less, in thickness, and it is divided into an anterior (or upper) electron-dense region and a less dense granular region posterior to this. This latter region appears finely striated at higher magnification (Fig. 2E). The combined acrosomal and plasma membranes were often slightly disassociated from the operculum in this region and appear as a convoluted, but not broken, membrane separated from the electrondense operculum.

The rest of the acrosome vesicle contents are arranged in four concentric zones (Fig. 2B, C): 1) a subopercular zone, 2) an inner acrosome zone, 3) an outer acrosome zone, and 4) a peripheral acrosome zone. Each of these zones is of differing appearance and electron density.

1. The subopercular zone basically fills the interior of the large, flat cone that is the operculum and has the appearance of a homogeneous finely granular matrix. Anteriorly, it is separated from the underside of the operculum by a thin electron-lucent band, and posteriorly it abuts the perforatorial chamber (Fig. 2B, C, E).

2. The inner acrosome zone extends through the centre of the acrosome vesicle thinly surrounding the perforatorial chamber. It is subjacent to the subopercular zone, at which point it is most extensive, and then attenuates into a thin 


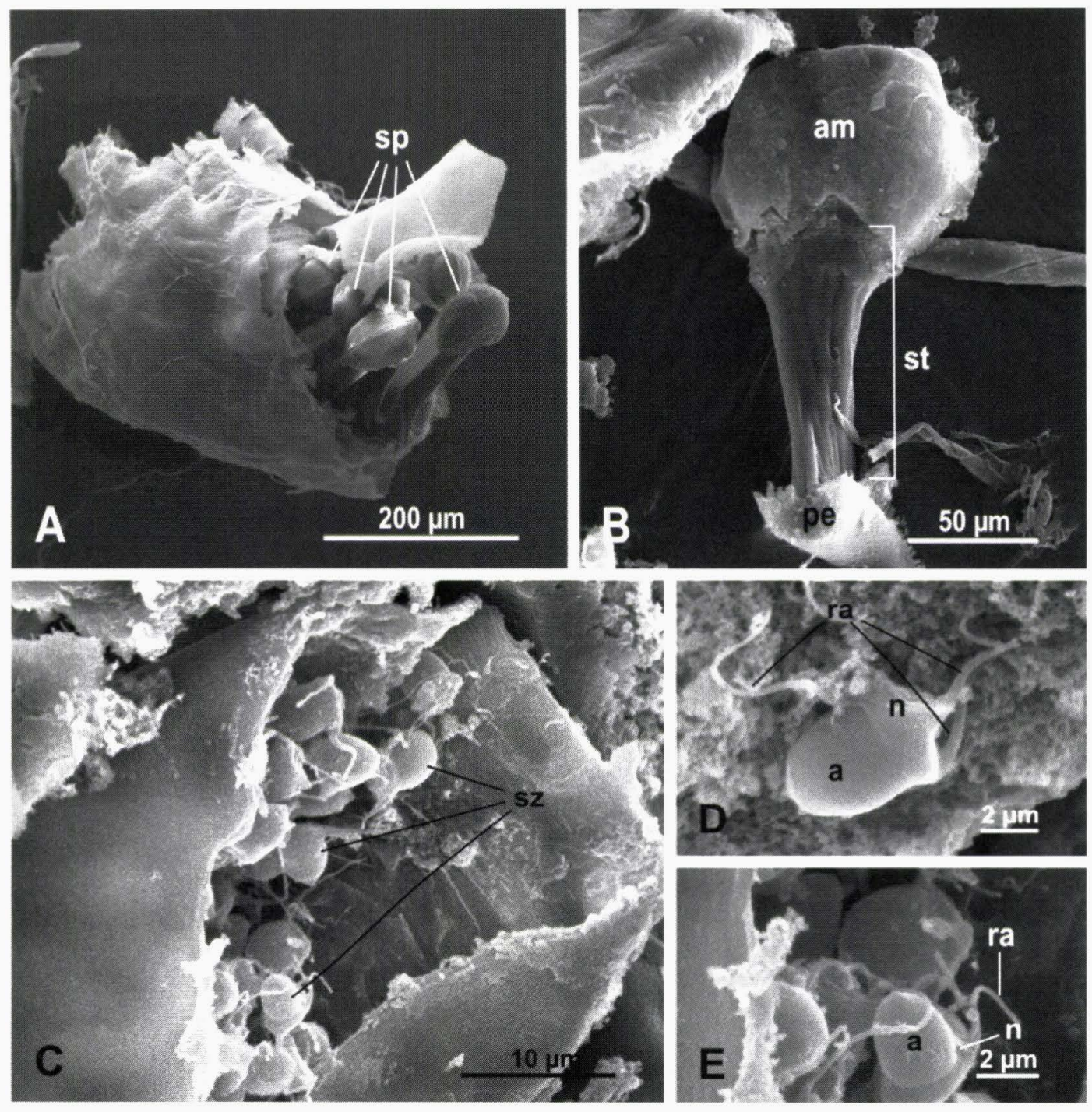

Fig. 1. Scanning electron micrographs of spermatophores and spermatozoa of Loxopagurus loxochelis. A, group of spermatophores (sp) in the vas deferens. B, each single spermatophore consists of terminal ampulla (am), stalk or peduncle (st), and pedestal (pe). C, open ampulla showing spermatozoa (sz). D, E, detail of sperm cells. a: acrosome vesicle region, $\mathbf{n}$ : nuclear region, ra: radial microtubular arms.

region posteriorly. It is of similar appearance to the subopercular zone but sometimes is slightly more electron-dense (Fig. 2B-D).

3. Exterior to the inner acrosome zone, and forming a thick, moderately electron-dense ring, is a zone termed the outer acrosome zone. It extends from the apical end of the acrosome vesicle (subjacent to the operculum), posteriorly, to terminate at the base of the acrosome vesicle, encircling the perforatorial chamber opening. It has similar granularity and electron density to the subopercular and inner acrosome zones, but in some micrographs can be seen to be made up of radiating lighter and darker lines, at best, and more usually irregular dark and light patches (Fig. 2B-E).

4. The peripheral acrosome zone extends around the periphery of the acrosome vesicle, 

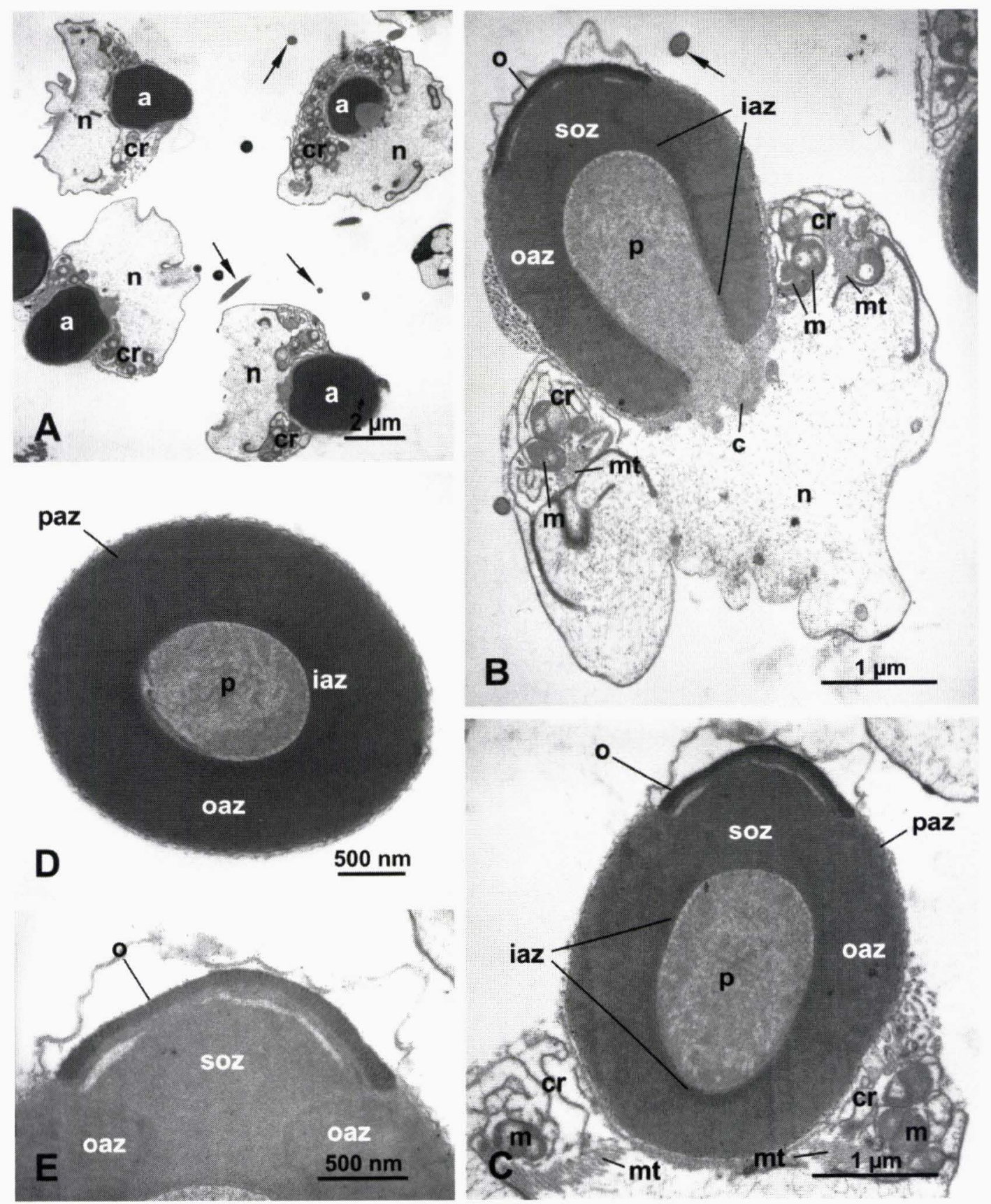

Fig. 2. Transmission electron micrographs of Loxopagurus loxochelis spermatozoa. A, oblique sections through several sperm cells. B, longitudinal section of entire spermatozoa. C, oblique section through acrosome vesicle and cytoplasm. D, transverse section of the acrosome vesicle. E, anterior end of the acrosome vesicle (longitudinal section). a: acrosome vesicle, $\mathbf{c}$ : centriole, cr: cytoplasmic ring, iaz: inner acrosome zone, $\mathbf{m}$ : mitochondria, $\mathbf{m t}$ : microtubules, $\mathbf{n}$ : nucleus, $\mathbf{o}$ : operculum, oaz: outer acrosome zone, p: perforatorial chamber, paz: peripheral acrosome zone, soz: subopercular zone. Arrows, transverse and oblique sections of microtubular arms. 
exterior to the inner and outer acrosome zones, from the operculum to the base of the perforatorial chamber. This zone is a homogeneously granular, yet very thin electron-pale zone which is barely distinguishable in many micrographs (Fig. 2C, D).

The perforatorial chamber is a large invagination into the posterior region of the acrosome vesicle. At its widest point, it is $1.2 \mu \mathrm{m}$ in diameter $(n=6)$, and extends into the acrosome vesicle for approximately $2.4 \mu \mathrm{m}(n=2)$. Light and TEM observations indicate that the perforatorial chamber has a circular outline when viewed in TS (Fig. 2D), and its contents are moderately electron-dense irregular patches of coarse granularity on an electron-lucent background (Figs. 2B-D; 3D, F, G). The smooth internal wall of the perforatorial chamber is not broken by any projecting microvilli, fingers or septae. An indistinct boundary, without any visible membrane, separates the perforatorial chamber contents from the subjacent cytoplasm.

The cytoplasm forms an enveloping layer, or ring, around the base of the acrosome vesicle (Figs. 2A, B; 3E-G). The cytoplasm is thickest laterally as a $1.2 \mu \mathrm{m}(n=4)$ high ring or collar, and attenuates directly below the perforatorial chamber. It is composed of a heterogeneous assemblage of moderately electron-dense organelles and other sub-cellular structures. These organelles include many spherical, acristate or sparsely cristate, electron-lucent mitochondria (concentrated in the lateral ring), irregular membrane systems (including the occasional almost regular whorl-like arrangement), various granules and vesicles, and bundles of microtubules (Figs. 2B, C; 3E-G). These bundles are the internal regions of the three microtubular arms (Fig. 3A, C, F, G) that are visible in transverse section in the extracellular matrix around the sperm cells (Figs. 2A, B; 3C). Some thickened cytoplasmic membranes are often directed posteriorly into the nuclear material for considerable lengths. In the finely granular cytoplasm directly below the perforatorial chamber, opening is sometimes visible a single centriole (pre- sumably one of a pair), although it is often very diffuse in appearance and difficult to discern any details of its microtubular arrangement (Fig. 3D, E).

In many of the sperm cells, a small region of anastomozing tubules and vesicles are visible between the acrosome vesicle membrane and the plasma membrane immediately anterior to the cytoplasmic ring (Fig. 3F, G). The tubular contents of these bulges are continuous with the cytoplasmic ring, but did not appear to extend into it. The small tubules in this region are larger (approx. $0.04 \mu \mathrm{m}$, or greater) than standard microtubules (approx. $0.02 \mu \mathrm{m}$ ), and they are generally consistent in diameter and moderately electron-dense. These tubules and vesicles were observed in both TS (Fig. 3F) and LS (Fig. 3G) of the sperm cells and usually appeared as a filled bulge or bubble emerging externally from the acrosome vesicle. In many TSs of the acrosome vesicle, this patch of tubules deforms the acrosome vesicle inwards, disrupting the normally circular profile of the acrosome (Fig. 3F, G).

The nuclear material is an amorphous, posteriorly directed plume of electron-lucent matrix, broken occasionally by small patches of more electron-dense granules and thickened cytoplasmic membranes. The nucleus is always bounded by a thick, electron-dense membrane, constituted by both the nuclear and plasma membranes (Figs. 2A, B; 3D-G).

\section{DISCUSSION}

The spermatozoal morphology exhibited by Loxopagurus loxochelis shows characters (symplesiomorphies) that are shared by other paguroids, and indeed, by many anomurans (Tudge \& Jamieson, 1991, 1996a, b; Tudge, 1992, 1995a, b, 1996, 1997; Tudge et al., 1998; Jamieson \& Tudge, 2000, and references therein). These include a complex concentrically zoned acrosome vesicle capped by an electrondense operculum and posteriorly penetrated by a perforatorial chamber, and three or more microtubular arms emanating from the cyto- 

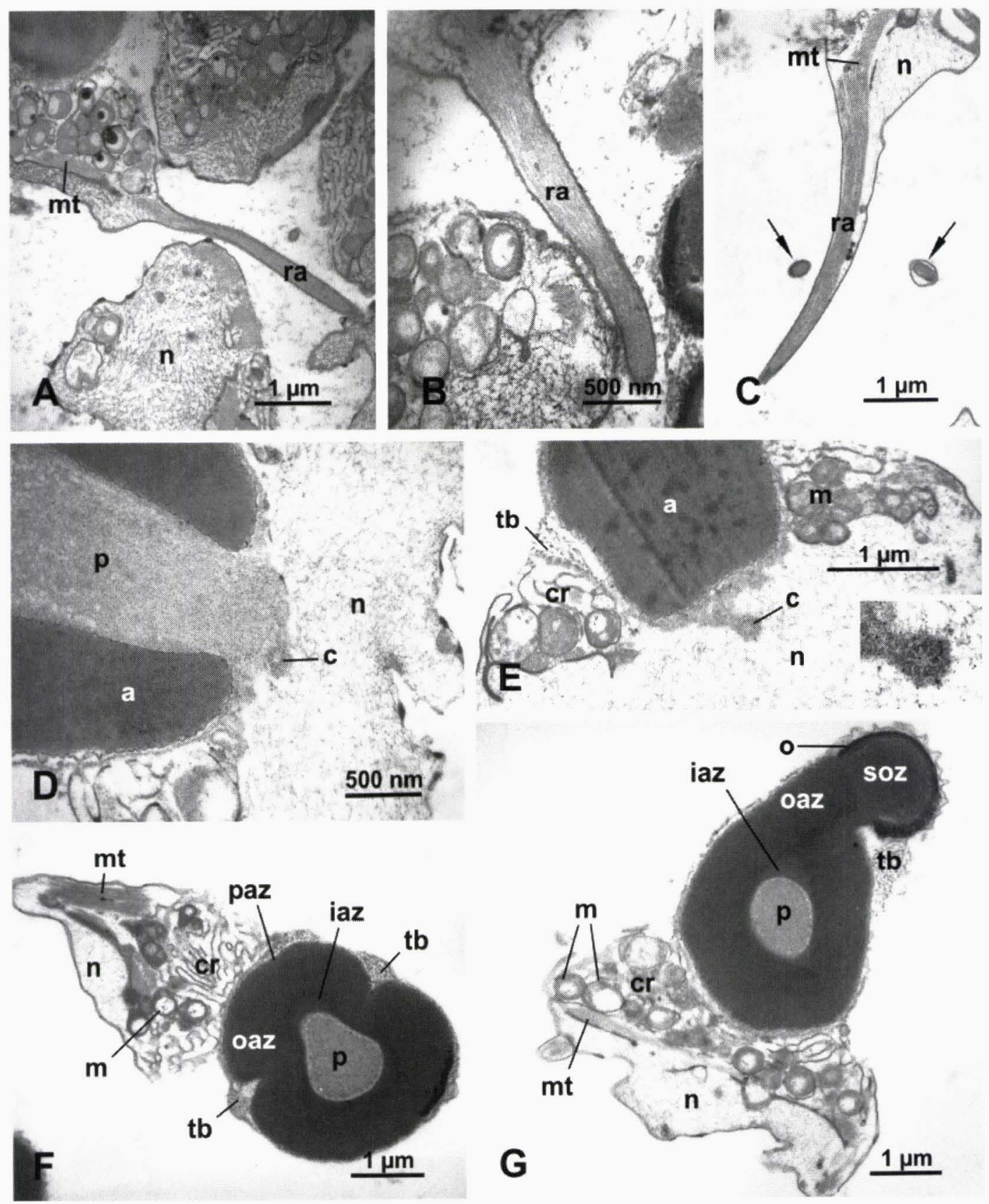

Fig. 3. Transmission electron micrographs of Loxopagurus loxochelis spermatozoa. A-C, longitudinal sections of radial microtubular arms (ra). D, E, partial views of the acrosome vesicle (basal part) (a) and nucleus (n), showing one centriole (c) in the subacrosomal cytoplasm below the perforatorial chamber (p) (the inset in $\mathrm{E}$ is an enlarged micrograph of the centriole). F, G, oblique sections of spermatozoa bearing tubule-containing cytoplasmic bulges (tb) that disrupt the normally regular profile of the acrosome. cr: cytoplasmic ring, iaz: inner acrosome zone, $\mathbf{m}$ : mitochondria, mt: microtubules, o: operculum, oaz: outer acrosome zone, paz: peripheral acrosome zone, soz: subopercular zone. Arrows, sections of microtubular arms. 
plasm of the sperm cell. A spherical to oblongovoid or cylindrical acrosome vesicle shape predominates in the Anomura, and length:width ratios of approximately 1.0 or more have been recorded in all investigated anomuran species (Tudge, 1995a, 1997) with the exception of Pylocheles in the Pylochelidae (Tudge et al., 2001). Loxopagurus, with a length:width ratio of 1.2 , falls well within the bulk of the paguroid hermit crabs. In all other anomurans investigated for sperm ultrastructure, three or more microtubular arms are composed of very visible bundles of microtubules, which often can be linked directly with the same structures within the cytoplasm (Tudge \& Jamieson, 1991; Tudge, 1992, 1995a, b; Tudge et al., 1998; Jamieson \& Tudge, 2000, and references therein). In this regard, Loxopagurus is no different from these other anomurans.

In overall sperm morphology, Loxopagurus loxochelis is most like that described for the diogenid genus Calcinus (Tudge, 1995a, b), and to a slightly lesser extent to the genus Strigopagurus (Tudge, 1996). The general sperm cell dimensions, operculum shape, subopercular zone presence and shape, and the number, appearance and arrangement of the other acrosome zones are most similar to those previously described for three species of Calcinus. Loxopagurus sperm cells lack the defining autapomorphy of Calcinus, which is the splitting of the anterior end of the perforatorial chamber into many obvious fingers. Also, it does not share the presence of microvillar projections in the interior wall of the perforatorial chamber as seen in all other investigated diogenid species (with the exception of a single member in the genus Cancellus) and members of the Coenobitidae. This absence of microvillar projections is a character shared with all investigated Paguridae, Parapaguridae and Lithodidae (Tudge, 1997; Tudge et al., 1998). If the faint striations that are sometimes observed in the outer acrosome zone are indicative of a more typical acrosome ray zone, then it shares this distinctive character with all coenobitids and the genera Dardanus and Diogenes in the Diogenidae (Tudge, 1992, 1995a, b, 1997).
A less convincing similarity is seen with the sperm morphology described for Strigopagurus boreonotus. The sperm of Loxopagurus share the general opercular shape and the presence and arrangement of the subopercular, inner acrosome, outer acrosome and peripheral acrosome zones. However, both the acrosome vesicle and perforatorial chamber are more spherical in the former species, and more importantly, Strigopagurus sperm possess small microvillar projections in the posterior end of the perforatorial chamber.

The only unique character observed in the sperm of Loxopagurus is the vesicle or bulge on the side of the acrosome filled with small tubules. This vesicle is most probably an artifact or possibly a parasitic bacterial infection. The small tubules appear, at least superficially, to resemble the Rickettsia bacteria, Wolbachia species, previously found in the cytoplasm of reproductive cells (both sperm and eggs) of other arthropods (Johanowicz \& Hoy, 1998; Van Der Geest et al., 2000), including crustaceans (Wolbachia web page: http://www. wolbachia.sols.uq.edu.au/hosts.cfm), but they are here much smaller than general rickettsial bacteria. Further investigations may reveal the exact nature of these tiny tubules.

What does the ultrastructure of the spermatozoa of Loxopagurus reveal about the relationship of this genus to other diogenid hermit crabs? The spermatophore morphology of Loxopagurus is most similar to that of the diogenid genus Clibanarius (see Scelzo et al., 2004), but the spermatozoal data do not support this relationship more than other diogenid genera like Calcinus or Strigopagurus. Clibanarius sperm possess two good apomorphies (possibly autapomorphies), the particular bulb shape of the perforatorial chamber and the obvious dense perforatorial ring around the posterior bulb of the perforatorial chamber (Tudge, 1992, 1995a, b, 1997). They also possess obvious and numerous microvillar projections in the perforatorial chamber, of which Loxopagurus sperm are lacking.

In conclusion, Loxopagurus loxochelis sperm morphology does not demonstrate any 
clear apomorphies, but seems to separate it from the other genera in the Diogenidae by the absence of their defining sperm characters (e.g. anterior perforatorial fingers and microvillar projections). It appears most similar to that of the genus Calcinus, and more superficially Strigopagurus, although its spermatophore morphology seems to indicate a closer relationship with Clibanarius. The combination of spermatophore and spermatozoal characters clearly places it in the Diogenidae, but also supports its monotypic status. Recent molecular evidence (Mantelatto et al., 2002) places Loxopagurus close to another unusual diogenid genus Isocheles; a view first presented by Forest (1964) when he erected the genus Loxopagurus. Investigation of the spermatophore and spermatozoal ultrastructure of Isocheles will be very revealing and should be a good test for the suggested molecular relationship.

Acknowledgements.-Rafael Lemaitre and previous chairs of the Department of Invertebrate Zoology, NMNH, Smithsonian Institution, USA, are thanked for supporting access to departmental facilities by CCT. This study has been partially supported by the Spanish government (Project REN2001-2875/ MAR), Mar del Plata National University (Project 15/E226) and CONICET (PIP 5135/05), Argentina. We also thank the staff of the Electron Microscopy units of the UNMdP and the University of Cádiz and Curro Abascal for invaluable help during preparation of the figures. Barrie Jamieson and David Scheltinga are thanked for their constructive and encouraging reviews of the paper, which is improved by their input.

\section{LITERATURE CITED}

Bauer, R.T., 1986. Phylogenetic trends in sperm transfer and storage complexity in decapod crustaceans. Journal of Crustacean Biology, 6: 313325.

Bauer, R.T., 1991. Sperm transfer and storage structures in penaeoid shrimps. A functional and phylogenetic perspective. In: R.T. Bauer \&
J.W. Martin, (eds.), Crustacean Sexual Biology, Columbia University Press, New York, pp. 183207.

Bernardi, J.V.E., 1986. Desenvolvimento larval de Loxopagurus loxochelis (Moreira, 1901) (Crustacea, Decapoda, Diogenidae) em laboratório. 33 pp. Bachelor Thesis Ecology, Universidade Estadual Paulista (unpublished).

Boschi, E. E., Fischbach, C. E., \& Iorio, M. I., 1992. Catálogo ilustrado de los crustáceos Estomatópodos y Decápodos marinos de Argentina. Frente Marítimo, 10: 1-94, figs. 198. Montevideo. Uruguay.

Forest, J., 1964. Sur un nouveau genre de Diogenidae (Crustacea Paguridea) de l' Atlantique Sud-Américain, Loxopagurus gen. nov., établi pour Pagurus loxochelis Moreira. Zoologische Mededelingen, 39: 279-296.

Forest, J., 1995. Crustacea Decapoda Anomura: revision du genre Trizopagurus Forest, 1952 (Diogenidae), avec l'établissement de deux genres nouveaux. In: A. Croisnier, (ed.), Résultats des Campagnes MUSORTOM. Mémoires Museum national d'Histoire naturelle, Paris, 163: 9-149.

Forest, J., \& de Saint Laurent, M., 1967. Crustacés Décapodes: Pagurides. Campagne de la Calypso au large des cotes Atlantiques de l'Amérique du sud (1961-1962). I. Annals Institute Océanographique, 45(2): 47-170.

Hinsch, G.W., 1991. Structure and chemical content of the spermatophores and seminal fluid of reptantian decapods. In: R.T. Bauer \& J.W. Martin, (eds.), Crustacean Sexual Biology, Columbia University Press, New York, pp. 290-307.

Jamieson, B. G. M., 1991. Ultrastructure and phylogeny of crustacean spermatozoa. Memoirs of the Queensland Museum, 31: 109-142.

Jamieson, B. G. M., \&. Tudge, C. C., 2000. 1. Decapoda (Crustacea): In: K. G. Adiyodi, \& R. G. Adiyodi (eds.), Reproductive Biology of Invertebrates. Vol. IX, part C, Progress in Male Gamete Ultrastructure and Phylogeny. Oxford \& IBH Publishing Co., New Delhi, pp. 1-95.

Johanowicz, D. L., \& Hoy, M. A., 1998. The manipulation of arthropod reproduction by Wolbachia endosymbionts. Florida Entomologist, 81(3): 310 -317 .

Krol, R. M., Hawkins, W. E., \& Overstreet, R. M., 1992. Reproductive components. In: F.W. Harrison \& A. G. Humes (eds.), Microscopic Anatomy of Invertebrates, Vol.10, Decapod Crustacea, Willey-Liss., New York, pp. 295-343.

Manjón-Cabeza, M. E., \& García Raso, J.E., 2000. Morphological reproductive aspects of males of Diogenes pugilator (Roux, 1829) (Crustacea, Decapoda, Anomura) from southern Spain. Sarsia, 85: 195-202. 
Mantelatto, F. L., \& Martinelli, J. M., 2001. Relative growth and sexual dimorphisms of the south Atlantic hermit crab Loxopagurus loxochelis (Anomura, Diogenidae) from Ubatuba, Brazil. Journal of Natural History, 35: 429-437.

Mantelatto, F. L., Martinelli, J. M., \& Fransozo, A., 2004. Temporal-spatial distribution of the hermit crab Loxopagurus loxochelis (Anomura, Diogenidae) from Ubatuba Bay, São Paulo State, Brazil. Revista Biología Tropical, 52(1): 47-55.

Mantelatto, F. L., Robles, R., Biagi, R., Felder, D. L., \& Scelzo, M. A., 2002. Molecular phylogenetic investigation of the hermit crab Loxopagurus loxochelis (Diogenidae) from the Brazilian and Argentinian provinces. In: Livro de Resumos do II Congresso Brasileiro sobre Crustáceos, São Pedro, Brazil, 10-14 November 2002, p. 184.

Martin, J. W., \&. Davis, G. E., 2001. An Updated Classification of the Recent Crustacea. Science Series 39, 124 pp., Natural History Museum of Los Angeles County.

Martinelli, J. M., \& Mantelatto, F. L., 1998. Occurrence of exobionts in gastropod shells occupied by the hermit crab Loxopagurus loxochelis (Anomura: Diogenidae) in Ubatuba Bay (SP), Brazil. In Anais do IV Simpósio de Ecossistemas Brasileiros, Vol. 2, ACIESP, São Paulo, pp. 221226.

Martinelli, J. M., \& Mantelatto, F. L., 1999. Shell occupation by the hermit crabs Loxopagurus loxochelis (Moreira, 1901) (Anomura, Diogenidae) from Ubatuba Bay, Brazil. In: F. R. Schram \& J. C. Vaupel Klein (eds.), Crustacea and the Biodiversity Crisis, Brill, Leiden, The Netherlands, pp. 719-731.

Martinelli, J. M., Mantelatto, F. L. M., \& Fransozo, A., 2002. Population structure and breeding season of the south Atlantic hermit crab, Loxopagurus loxochelis (Anomura, Diogenidae) from the Ubatuba region, Brazil. Crustaceana, 75(6): 791-802.

Matos, E., Matos, P., Oliveira, E., \& Azevedo, C., 1993. Aspectos morfológicos e ultraestruturais do espermatozóide de ermitão Clibanarius vittatus Bosc, 1802 (Crustacea, Decapoda) do litoral norte do Brasil. Revista Brasileira de Ciências Morfológicas, 10(2): 126-131.

McLaughlin, P. A., 1983. Hermit crabs - are they really polyphyletic? Journal of Crustacean Biology, 3: 608-621.

McLaughlin, P. A., 2003. Illustrated keys to families and genera of the superfamily Paguroidea (Crustacea: Decapoda: Anomura), with diagnoses of genera of Paguridae. Memoirs of Museum Victoria, 60(1): 111-144.

McLaughlin, P., \& Holthuis, L. B., 1985. Anomura versus Anomala. Crustaceana, 49: 204-209.

McLaughlin, P. A., \& Lemaitre, R., 2001. A new family for a new genus and new species of hermit crab of the superfamily Paguroidea (Decapoda: Anomura) and its phylogenetic implications. Journal of Crustacean Biology, 21(4): 1062-1076.

Melo, G. A. S., 1999. Manual de indentificação dos Crustacea Decapoda do litoral brasileiro: Anomura, Thalassinidea, Palinuridea, Astacidae. São Paulo, Ed. Plêiade.

Moreira, C., 1901. Contribuicões para o conhecimento da fauna brazileira. Crustáceos do Brasil. Archivos do Museu nacional. Rio de Janeiro, 11: $1-151$.

Reynolds E. S., 1963. The use of lead citrate at high $\mathrm{pH}$ as an electron opaque stain in electron microscopy. Journal of Cell Biology, 17: 208-212.

Rieger, P. J., \& D'Incao, F., 1991. Distribuição das larvas de Loxopagurus loxochelis (Decapoda, Diogenidae) na região adjacente a Barra de Rio Grande, RS. Nerítica, 6(1-2): 93-106.

Scelzo, M. A., 1971. Un nuevo cangrejo ermitaño Paguristes foresti n.sp. para aguas Argentinas. (Decapoda, Diogenidae). Neotropica, 17 (54): 146-152.

Scelzo, M. A., 1973. Lista de los Crustáceos Decápodos Anomura obtenidos en 1966 por la Expedición Walther Herwig, en Atlántico Sur y depositados en las colecciones del Instituto de Biología Marina. Physis, Sec.A., 32 (84): $161-$ 174.

Scelzo, M. A., 1976. Larvas de los crustáceos decápodos anomuros identificados en las aguas marinas Argentinas. Physis, 35(90): 37-45.

Scelzo, M. A. \& Boschi, E. E., 1973. Aportes al conocimiento de la distribución geográfica de los Crustáceos Decápodos Anomura del Atlántico Sudoeste, frente a las costas de la Argentina. Trabajos V Congreso Latinoamericano de Zoologia, 1: 204-216.

Scelzo, M. A., Martinez-Arca, J., \& Lucero, N. M., 2002. Diversidad, densidad y biomasa de la macrofauna componente del sistema de pesca "camarón-langostino," frente a Mar del Plata, Argentina. Revista de Investigación y Desarrollo Pesquero (INIDEP), No 15: 43-65.

Scelzo, M. A., Mantelatto, F. L., \& Tudge, C. C., 2004. Spermatophore morphology of the endemic hermit crab Loxopagurus loxochelis (Anomura, Diogenidae) from Southwestern Atlantic - Brazil and Argentina. Invertebrate Reproduction and Development, 46(1): 1-9.

Scholtz, G., \& Richter, S., 1995. Phylogenetic systematics of the reptantian Decapoda (Crustacea, Malacostraca). Zoological Journal of the Linnean Society, 113: 289-328.

Spurr, A. R., 1969. A low viscosity epoxy-resin embedding medium for electron microscopy. Journal of Ultrastructure Research, 26: 31-43. 
Tudge, C. C., 1992. Comparative ultrastructure of hermit crab spermatozoa (Decapoda: Anomura: Paguroidea). Journal of Crustacean Biology, 12: $397-409$.

Tudge, C. C., 1995a. The Ultrastructure and Phylogeny of Anomuran Crab Spermatozoa. Ph.D. Thesis, 346 pp., Zoology Department, The University of Queensland, Brisbane, Australia.

Tudge, C. C., 1995b. Ultrastructure and phylogeny of the spermatozoa of the infraorders Thalassinidea and Anomura (Decapoda, Crustacea). In: B. G. M. Jamieson, J. Ausio \& J.-L. Justine (eds.), Advances in Spermatozoal Phylogeny and Taxonomy. Mémoirs du Muséum national d'Histoire naturelle, Paris, 166: 251263.

Tudge, C. C., 1996. Spermatophore morphology and spermatozoal ultrastructure of the recently described hermit crab, Strigopagurus boreonotus Forest, 1995 (Decapoda, Anomura, Diogenidae). Bulletin du Muséum national d'Histoire naturelle, Paris, 18 (3-4): 547-555.

Tudge, C. C., 1997. Phylogeny of the Anomura (Decapoda, Crustacea): Spermatozoa and spermatophore morphological evidence. Contributions to Zoology, 67: 125-141.

Tudge, C. C., \& Jamieson, B. G. M., 1991. Ultrastructure of the mature spermatozoon of the coconut crab Birgus latro (Coenobitidae: Paguroidea: Decapoda). Marine Biology, 108: $395-402$.

Tudge, C. C., \& Jamieson, B. G. M., 1996a. Spermatophore and spermatozoal morphology in the Porcellanidae. I. Aliaporcellana suluensis and Pisidia longicornis (Decapoda, Anomura, Porcellanidae). Crustacean Research, 25: 73-85.

Tudge, C. C., \& Jamieson, B. G. M., 1996 b. Spermatophore and spermatozoal morphology in the Porcellanidae. II. The genera Petrolisthes and Polyonyx (Decapoda, Anomura, Porcellanidae). Journal of Crustacean Biology, 16: 535-546.

Tudge, C. C., \& Scheltinga, D. M., 2002.
Spermatozoal morphology of the freshwater anomuran Aegla longirostris Bond-Buckup \& Buckup, 1994 (Crustacea: Decapoda: Aeglidae) from South America. Proceedings of the Biological Society of Washington, 115(1): 118128.

Tudge, C. C., Scheltinga, D. M., \& Jamieson, B. G. M., 2001. Spermatozoal morphology in the "symmetrical" hermit crab, Pylocheles (Bathycheles) sp. (Crustacea, Decapoda, Anomura, Paguroidea, Pylochelidae). Zoosystema, 23(1): 117-130.

Tudge, C. C., Scheltinga, D. M., \& Jamieson, B. G. M., 1999. Spermatozoal ultrastructure in the Hippoidea (Anomura, Decapoda). Journal of Submicroscopic Cytology and Pathology, 31(1): $1-13$.

Tudge, C. C., Jamieson, B. G. M., Sandberg, L., \& Erséus, C., 1998. Ultrastructure of the mature spermatozoon of the king crab Lithodes maja (Lithodidae, Anomura, Decapoda): Further confirmation of a lithodid-pagurid relationship. Invertebrate Biology, 117: 57-66.

Van Der Geest, L. P. S., Elliot, S. L., Breeuwer, J. A. J., \& Beerling, E. A. M., 2000. Diseases of mites. Experimental and Applied Acarology, 24: 497560.

Addresses: MAS, Departamento de Ciencias Marinas, FCEyN, Universidad Nacional de Mar del Plata/CONICET, Funes 3350, Mar del Plata, Argentina; e-mail: mascelzo@mdp.edu.ar. AM, Departamento de Biología, Facultad de Ciencias de Mar y Ambientales, Avda. República Saharaui, s/n, E-11510, Puerto Real, Cádiz, Spain; e-mail: antonio. medina@uca.es. *CCT, Department of Invertebrate Zoology, MRC 163, National Museum of Natural History, Smithsonian Institution, Washington, D.C. 20013-7012, U.S.A. and Department of Biology, American University, Washington, D.C. 20016-8007, U.S.A.; e-mail: tudgec@si.edu

*Author for correspondence 